\title{
Quality characteristics of Jook prepared with peanut (Arachis hypogaea L.) powder
}

\author{
Bock-Hee Park ${ }^{1}$, Seon-Hee Kim ${ }^{1}$, Kyung-Jo Park ${ }^{1}$, Hee-Sook Cho ${ }^{2 *}$ \\ ${ }^{1}$ Department of Food and Nutrition, Mokpo National University, Muan 58544, Korea \\ ${ }^{2}$ Department of Culinary Art, Chodang University, Muan 58530, Korea
}

\section{땅콩분말을 첨가한 죽의 품질 특성}

\author{
박복희 ${ }^{1} \cdot$ 김선희 $^{1} \cdot$ 박경조 $^{1} \cdot$ 조희숙 $^{2 *}$ \\ ${ }^{1}$ 목포대학교 식품영양학과, ${ }^{2}$ 초당대학교 조리과학부
}

\begin{abstract}
This study was conducted to evaluate the effects of peanut (Arachis hypogaea $\mathbf{L}$.) powder on the physicochemical and sensory characteristics of Jook. The proximate composition of peanut powder was as follows: moisture, $1.8 \%$; crude protein, 24.9\%; crude lipid, $48.3 \%$; crude ash, 2.9\%; and carbohydrates, $22.1 \%$. Each sample of Jook contained $20 \%, 40 \%, 60 \%$ and $80 \%$ of peanut powder when compared to the control, and their physicochemical properties were assessed. As the peanut powder content increased, there was a significant decrease in $\mathbf{p H}(\mathbf{p}<0.05)$ In addition, Hunter's color $L$ value decreased, whereas Hunter's color a and $b$ values increased with increasing addition of peanut powder. The Jook showed lower spreadability and higher viscosity values as the peanut powder content increased. The results of the sensory evaluation showed that the Jook containing 40 60\% peanut powder had the highest score. According to the overall preference, addition of $40 \%$ peanut powder positively affected the quality characteristics of Jook. These results suggest that peanut powder can be applied to Jook to achieve beneficial effects on the quality and functionality.
\end{abstract}

Key words : Jook, peanut powder, sensory evaluation, quality characteristics

\section{서 론}

죽은 일반적으로 쌀, 보리, 조 등의 곡류에 물을 6 7배 가량 붓고 오래 끓여서 녹말이 완전히 호화된 상태로 무르 익게 만든 유동식이다. 쌀을 이용한 흰죽이 기본이지만 다 른 곡물을 섞어쓰기도 하며, 곡물에 여러 가지 채소나 산초, 약초를 섞어 효능을 높이기도 한다(1). 죽은 열량 공급뿐만 아니라 먹기가 간편하고 소화가 잘되어 부담이 없기 때문에 아침식, 노인식, 치료식, 이유식 등으로 다양하게 이용이 가능하다(2). 요즘에는 간편식으로 수요가 더욱 증가하고

*Corresponding author. E-mail : hscho61@hanmail.net Phone : 82-61-450-1645, Fax : 82-61-450-1641

Received 17 July 2015; Revised 5 October 2015; Accepted 5 October 2015.

Copyright (c) The Korean Society of Food Preservation. All rights reserved.
있으며, 통조림이나 레토르트 식품 등으로도 시판되고 있 다(3). 국민소득의 향상과 함께 소비자의 고품질 식품에 대한 기호도의 증가와 건강에 관한 관심의 증가로 기능성이 있는 소재인 새우(4), 연근분말(5), 연잎분말(6), 인삼(7), 마 (8), 해조 분말(9), 모시잎(10), 자색고구마(11), 현미(12), 우 엉(13), 노루궁뎅이버섯(14) 등의 재료를 사용하여 영양과 기호도를 높이는 죽류에 관한 연구가 계속적으로 이루어지 고 있다.

최근 웰빙에 대한 소비자들의 관심이 높아짐에 따라 매 일 섭취하는 식품을 통하여 질병을 예방하고 건강할 수 있다는 생각들이 소비 트랜드에 영향을 주어 생리활성을 가진 우리 농산물을 이용해 식품소재로 하여 제품을 개발하 는 가공연구가 활발히 진행되고 있다(15).

땅콩(Arachis hypogaea L.)은 콩과(Leguminosae)에 속하 는 일년생의 초본식물로 우리나라에서는 예로부터 비교적 손쉽게 재배가 가능하여 식용으로 널리 사용되어져 왔다 
(16). 땅콩에는 지방과 단백질 함량이 높아 유지원료 작물로 서 뿐만 아니라 단백질 식품원으로서도 이용되며 $(17,18)$ 비타민이나 미네랄과 같은 유용한 생리활성 성분들이 많이 포함되어 있어 식품용이나 간식용뿐만 아니라 여러 가지 가공제품 원료로 이용되고 있다. 최근 연구에 의하면 땅콩 은 항암과 항산화와 같은 다양한 생리활성이 검증된 천연 폴리페놀계 화합물인 resveratrol물질을 다량 함유하고 있 음이 보고 $(19,20)$ 되면서 건강식품으로 주목을 받고 있다. 땅콩의 기능성에 대한 연구로는 동맥경화 예방효과(21), 항산화 활성 및 항암효과(22-26), 지질산화에 대한 방어 기 능 $(27,28)$ 등이 보고되었다. 세계적으로 이용되는 땅콩 소 비양상을 용도별로 구분해보면 기름용(조리용 튀김기름), 샐러드용, 가공용(salted seed, 땅콩버터, 마가린, 캔디, 쿠키 등 제과용 및 제빵용), 아이스크림용 및 부재료 등으로 쓰이 고 단백질 공급원으로 플레이크, 분말 등의 형태로 공급된 다(29). 땅콩은 아직까지는 수입산에 의존하는바 무공해 국내산 땅콩 수요계층 확대에 따른 가공, 포장 기반이 미약 한 점을 개선하는 일이 중요하다. 또한 직장인들의 주 5일 근무제에 따른 레저활동 등으로 인한 소비 확산이 증가하는 추세인 점에 착안하여 땅콩을 이용한 가공품 개발에 대한 연구가 필요한 실정이다.

이에 본 연구에서는 땅콩이 갖고 있는 우수한 영양적 효능과 생리활성을 활용하여 영양적으로도 우수하면서 손 쉽게 많은 양을 소비할 수 있는 땅콩 분말을 첨가한 죽을 개발함으로써 땅콩죽의 제품화를 위한 기초 자료를 제시하 고자 하였다.

\section{재료 및 방법}

\section{실험재료}

본 실험에 사용한 땅콩 분말은 신안군에서 생산된 국내 산 땅콩을 구입하여 볶은 후 바람을 이용해 완전히 식힌 다음 껍질을 제거하고 분쇄기(롤러기, stainless재질)에서 분쇄기의 롤러기를 조정해서 5 회 반복하여 땅콩 분말을 제조하여 사용하였다. 찹쌀분말과 현미분말은 $\mathrm{e}$ 방앗간 (Kungbuk Uesung-gun Uesung-uep)에서 구입하여 사용하였 고, 전지분유(Seoul milk, Korea), 설탕(Samyang Co., Incheon, Korea), 소금은 천일염(Chungjungone, Korea)을 사 용하였다.

\section{땅콩분말의 일반성분 분석}

땅콩분말의 일반 성분은 $\mathrm{AOAC}$ 법(30)에 준하여 수분은 $105^{\circ} \mathrm{C}$ 건조법, 회분은 건식회화법, 조지방은 Soxhlet 추출법 으로 분석하였으며, 조단백질은 단백질 자동분석기(Kjeltec 2200 Auto Analyzer, Tecator, Sweden)을 이용하여 microKjeldahl법으로 분석하였다. 탄수화물은 시료 전체 무게(\%)
에서 수분, 회분, 조지방, 조단백질을 뺀 나머지 값을 \%로 표시하였다.

\section{땅콩분말 첨가 죽의 제조}

땅콩분말을 첨가한 죽은 땅콩 분말 첨가 수준을 달리하 여 제조하였는데, 예비실험을 통해 결정된 재료 배합비 Table 1에 따라 다른 재료의 조건은 모두 고정한 후 땅콩분 말의 첨가 비율을 0 (대조군), $20,40,60$ 및 $80 \%$ 로 달리하고 이에 따라 전지분유의 비율을 조정하여 배합하였다. 가수 량은 각 재료의 수분함량을 고려하여 혼합물의 수분함량이 $92.0 \%$ 가 되도록 조절하였다. 땅콩분말과 그 외의 재료들을 혼합한 재료와 물을 냄비 $(18 \mathrm{~cm} \times 9 \mathrm{~cm}$, 남선알미늄, 대구 $)$ 에 넣고, 이를 최고의 화력 강도(10번)로 10 분간 예열시킨 핫플 레이트(AK 2080, Rommelsbacher Elektrohausgerate Gmbh, Dinkelsbuhl, Germany)에 올려놓고 중불에서 10 분 동안 끓인 다음, 화력 강도를 낮추어 2 분 동안 더 가열하였다. 가열하는 동안 죽이 바닥에 눌러 붙지 않도록 천천히 저어 주었으며, 조리 직후 소금을 첨가하였다. 땅콩분말 첨가 죽의 준비는 물리적 특성 및 관능적 특성을 검사하기 약 30 분전에 마치고, 온도 변화를 줄이기 위해 제조 후 즉시 보온병(용량 $1.5 \mathrm{~L}$, 주식회사 세신, 경남 양산)에 담았다.

Table 1. Formula for peanut (Arachis hypogaea L.) Jook with added peanut powder

\begin{tabular}{lccccc}
\hline \multirow{2}{*}{\multicolumn{1}{c}{ Ingredients }} & \multicolumn{5}{c}{ Samples $^{1)}$} \\
\cline { 2 - 6 } & Control & PF-20\% & PF-40\% & PF-60\% & PF-80\% \\
\hline Whole milk powder & 100 & 80 & 60 & 40 & 20 \\
Peanut powder & 0 & 20 & 40 & 60 & 80 \\
Waxy rice flour & 30 & 30 & 30 & 30 & 30 \\
Brown rice flour & 25 & 25 & 25 & 25 & 25 \\
Sugar & 10 & 10 & 10 & 10 & 10 \\
Salt & 2 & 2 & 2 & 2 & 2 \\
Water $^{2)}(\mathrm{mL})$ & 500 & 520 & 545 & 560 & 585 \\
\hline
\end{tabular}

${ }^{1)}$ Control, no peanut powder; $\mathrm{PF}-20 \%, 20 \%$ peanut powder, $\mathrm{PF}-40 \%, 40 \%$ peanut powder, PF- $60 \%$, 60\% peanut powder, PF- $80 \%$, $80 \%$ peanut powder.

${ }^{2)}$ Water added in gruel preparation to have $92.0 \%$ moisture.

\section{땅콩분말 첨가 죽의 $\mathrm{pH}$}

$\mathrm{pH}$ 는 시료를 waring blender로 마쇄한 후 $20 \mathrm{~g}$ 을 취하여 증류수 $180 \mathrm{~mL}$ 로 희석하고 여과지(Whatman No. 5)로 여과 해서 그 여액을 사용하였으며, $\mathrm{pH} \operatorname{meter}(\mathrm{EA}$ 920, Orion Research INC., Hanna, Mauritius, USA)로 10회 반복하여 측정하였다.

\section{땅콩분말 첨가 죽의 색도}

땅콩분말 첨가 죽의 색도 측정은 색차계(CR-200, Minolta, Tokyo, Japan)를 이용하였고, 색도계 cell에 죽을 
가득 담아 명도(L : lightness), 적색도(a : redness), 황색도(b : yellowness) 값을 3회 반복 측정한 평균값으로 나타내었다. 색도 측정 시에는 땅콩분말 첨가 죽을 보온병에서 꺼내 $40^{\circ} \mathrm{C}$ 로 식혀 사용하였다. 이때 사용한 표준백판(standard plate)은 L값 $97.83, \mathrm{a}$ 값 $-0.43, \mathrm{~b}$ 값 1.98 이었다.

\section{땅콩분말 첨가 죽의 점도와 퍼짐성}

땅콩 죽의 점도 측정은 조리 후 수분 증발을 막기 위하여 비이커의 상부를 알미늄호일로 덮고 실온에 방치하여 죽의 온도가 $60^{\circ} \mathrm{C}$ 가 되었을 때 Brookfield viscometer(DV-II, Brookfield Engineering Laboratories, INC., Middleboro, MA, USA)를 사용하여 측정하였다. 시료는 $200 \mathrm{~mL}$ 를 취하며 spindle 4 를 사용하여 측정하였으며, spindle의 회전속도는 $100 \mathrm{rpm}$ 으로 하여 1 분이 지난 시점에서 점도를 3 회 반복 측정하여 평균값으로 나타내었다. 점도 값은 아래 식에 의 해 구하였다.

$n(\mathrm{cps})=$ Shear stress $\left(\right.$ dynes $\left./ \mathrm{cm}^{2}\right) /$ Shear rate $\left(\mathrm{sec}^{-1}\right)$

퍼짐성의 측정은 line spread chart를 사용하였다. Line spread chart의 측정은 $60^{\circ} \mathrm{C}$ 인 죽을 $50 \mathrm{~g}$ 취하여 지름과 높이 가 각각 $50 \mathrm{~mm}$ 인 투명 아크릴 원통 속에 넣은 후 원통을 들어 올려 퍼지게 하여 5 분 후 자로 퍼진 부분 4 군데의 부위에서 반지름을 5 회 측정하여 평균치를 구하였다.

\section{땅콩분말 첨가 죽의 관능검사}

땅콩 죽의 관능검사는 목포대학교 교육대학원생 20 명을 검사원으로 하여 실험 목적 및 검사 세부 항목에 대하여 이해를 시킨 후 검사에 응하도록 하였다. 관능검사 시간은 오후 3시로 하였으며 시료 번호는 난수표를 이용하여 3자 리 숫자로 하였다. 평가방법은 색깔, 향미, 맛 그리고 전반적 인 기호도 등에 대하여 5 점 기호 척도법으로 하여 아주 좋다 5점, 좋다 4점, 보통이다 3점, 나쁘다 2점, 아주 나쁘다 1점으로 하였다.

\section{통계처리}

평가결과의 통계처리는 IBM SPSS statistics(21, IBM Corp., Armonk, NY, USA)를 이용하여 평균 및 표준편차를 구하고, 분산분석(ANOVA)과 Duncan의 다중범위 시험법 (Duncan's multiple range test)으로 통계적 유의성을 검증하 였다 $(\mathrm{p}<0.05)$.

\section{결과 및 고찰}

\section{땅콩분말의 일반성분}

땅콩분말의 일반성분을 측정한 결과는 Table 2 와 같다. 땅콩분말은 수분함량 $1.8 \%$, 조단백질 $24.9 \%$, 조지방 $48.3 \%$,
회분 $2.9 \%$, 탄수화물 $22.1 \%$ 로 나타나 지방과 단백질의 함 량이 매우 높았다.

Table 2. Proximate composition of peanut powder

\begin{tabular}{lc}
\hline \multicolumn{1}{c}{ Characteristics } & Peanut powder \\
\hline Moisture (\%) & $1.8 \pm 0.01$ \\
Crude protein (\%) & $24.9 \pm 0.13$ \\
Crude lipid (\%) & $48.3 \pm 0.25$ \\
Crude ash (\%) & $2.9 \pm 0.03$ \\
Carbohydrate (\%) & $22.1 \pm 0.11$ \\
\hline
\end{tabular}

\section{땅콩분말 죽의 $\mathrm{pH}$ 와 색도}

땅콩분말 첨가량에 따른 땅콩 죽의 $\mathrm{pH}$ 는 Table 3 에 나타 난 바와 같다. 땅콩분말의 첨가수준이 증가함에 따라 대조 군, $20,40,60$ 및 $80 \%$ 땅콩분말 첨가 죽의 경우 $\mathrm{pH}$ 는 각각 $7.41,7.23,7.06,6.95,6.79$ 로 유의하게 감소 $(\mathrm{p}<0.05)$ 하였다. 연잎분말 첨가죽(6), 마 첨가죽(8), 자색고구마 첨가죽(10), 우엉 첨가죽(13), 아몬드 첨가죽(31), 파래분말 첨가죽(32) 의 경우 부재료 첨가량이 증가할수록 $\mathrm{pH}$ 가 감소되는 경향 을 나타냈다고 보고하여 본 결과와 같은 경향이었다.

땅콩분말 죽의 색도 측정 결과는 Table 3 에 나타난 바와 같다. 땅콩분말의 첨가량이 증가할수록 $\mathrm{L}$ 값(명도)은 대조 군의 경우 73.25로서 첨가군의 경우 70.95 63.25로 감소하 는 경향이었는데, 새우분말 첨가죽(4), 연근분말 첨가죽(5), 파래분말 첨가죽(32), 홍어 분말(33) 등의 경우 부재료의 첨가량이 증가할수록 $\mathrm{L}$ 값(명도)이 감소하였다고 보고하여 본 결과와 같은 경향이었다. $\mathrm{a}$ 값(적색도)의 경우 대조군에 서 -0.35 로 가장 낮았고 땅콩분말의 첨가량이 증가할수록 높아져(0.04 0.37) 적색도가 증가하는 것으로 나타났다. b 값(황색도)은 대조군의 경우 12.19 에서 땅콩분말의 첨가량 이 증가할수록 12.82 15.60으로 높아져 황색도가 증가하였 다. Park 등(6)의 연잎분말을 첨가한 죽의 연구에서도 색도 의 경우 연잎분말 첨가량이 증가할수록 $\mathrm{L}$ 값(명도)은 낮아

Table 3. $\mathrm{pH}$ and color of peanut (Arachis hypogaea L.) Jook with added peanut powder

\begin{tabular}{ccccc}
\hline \multirow{2}{*}{ Samples $^{1)}$} & \multirow{2}{*}{$\mathrm{pH}$} & \multicolumn{3}{c}{ Hunter's color values } \\
\cline { 3 - 5 } & & L (lightness) & $\mathrm{a}$ (redness) & $\mathrm{b}$ (yellowness) \\
\hline Control & $7.41 \pm 0.03^{\mathrm{a} 2)}$ & $73.25 \pm 0.52^{\mathrm{a}}$ & $-0.35 \pm 0.01^{\mathrm{c}}$ & $12.19 \pm 0.25^{\mathrm{d}}$ \\
PF-20\% & $7.23 \pm 0.02^{\mathrm{a}}$ & $70.95 \pm 0.45^{\mathrm{a}}$ & $0.04 \pm 0.02^{\mathrm{b}}$ & $12.82 \pm 0.27^{\mathrm{c}}$ \\
PF-40\% & $7.06 \pm 0.01^{\mathrm{b}}$ & $68.51 \pm 0.13^{\mathrm{b}}$ & $0.31 \pm 0.03^{\mathrm{a}}$ & $14.12 \pm 0.31^{\mathrm{b}}$ \\
PF-60\% & $6.95 \pm 0.01^{\mathrm{b}}$ & $65.30 \pm 0.12^{\mathrm{b}}$ & $0.35 \pm 0.02^{\mathrm{a}}$ & $14.55 \pm 0.35^{\mathrm{b}}$ \\
PF-80\% & $6.79 \pm 0.02^{\mathrm{c}}$ & $63.25 \pm 0.10^{\mathrm{b}}$ & $0.37 \pm 0.02^{\mathrm{a}}$ & $15.66 \pm 0.42^{\mathrm{a}}$ \\
\hline
\end{tabular}

${ }^{1)}$ Control, no peanut powder; PF-20\%, 20\% peanut powder; PF- $40 \%, 40 \%$ peanut powder; $\mathrm{PF}-60 \%, 60 \%$ peanut powder; $\mathrm{PF}-80 \%, 80 \%$ peanut powder.

${ }^{2)}$ Values are mean $\pm \mathrm{SD}$. Means with different superscripts within columns are significantly different by Duncan's multiple range test at $\mathrm{p}<0.05$. 
지고, $\mathrm{a}$ 값(적색도)과 $\mathrm{b}$ 값(황색도)은 증가하였고, 노루궁뎅 이버섯 첨가죽(14)에서도 부재료 첨가량이 증가할수록 $\mathrm{L}$ 값 (명도)은 낮아지고, $\mathrm{a}$ 값(적색도)과 $\mathrm{b}$ 값(황색도)이 증가하여 본 연구결과와 같은 경향을 보였다. 죽의 색도는 $\mathrm{pH}$, 당의 종류와 양, 온도 등에 많은 영향을 받게 되는데(6), 본 연구 에서도 색도의 결과는 땅콩분말 자체의 색에 더 영향을 받는 것으로 생각된다.

\section{땅콩분말 죽의 점도와 퍼짐성}

죽의 유동적 특성은 곡물의 입자크기, 고형물 함량, 조리 시간, 죽의 온도와 같은 요인들에 의해 영향을 받는데 특히 죽에서 중요한 유동적 특성은 점도와 관련되어 있다(34). 땅콩분말 첨가 죽의 점도와 퍼짐성을 측정한 결과는 Table 4 와 같다. 점도는 땅콩분말 첨가수준이 증가할수록 대조군, $20,40,60$ 및 $80 \%$ 땅콩분말 첨가 죽의 경우 각각 4753.25, $6531.33,6923.10,7255.21,7825.22$ 로 유의하게 증가 $(\mathrm{p}<0.05)$ 하였다. 한편, 퍼짐성은 대조군의 경우 8.33 에서 $20,40,60$ 및 $80 \%$ 땅콩분말 첨가군은 각각 $6.75,6.44,6.25$, 6.14 로 유의하게 감소하여 점도 증가에 따른 퍼짐성의 감소 $(\mathrm{p}<0.05)$ 를 나타내었다. Ahn 등(12)은 현미를 첨가한 타락 죽의 연구에서 현미 첨가량 증가에 따라 멥쌀 죽의 점도는 유의하게 감소하고, 찹쌀 죽의 점도는 유의하게 증가한다 고 보고하였으며, $\mathrm{Cho}$ 와 $\mathrm{Kim}(4)$ 은 새우 분말을 첨가한 죽의 경우 첨가량이 증가할수록 아밀로오스 용출이 최소화되어 점도는 유의하게 증가하였고, 퍼짐성은 감소되었다고 보고 하였다. 노루궁뎅이버섯 죽(14)의 경우에도 첨가수준의 증
가에 따라 점도가 유의하게 증가한다고 보고하였다. 이러 한 결과는 본 연구에서 찹쌀과 현미에 땅콩분말을 첨가한 죽을 제조하여 첨가량이 증가될수록 점도가 증가한 결과와 일치하였다. 멥쌀 죽의 경우와 찹쌀 죽의 경우 다른 양상을 보인 것은 아밀로오스와 아밀로펙틴의 함량차이와 구조적 차이에 기인하는 것으로 여겨진다. 한편, 마 첨가 죽(8), 아몬드 첨가 죽(31), 은행분말 첨가 죽(35), 호박 첨가 죽(36) 의 경우에는 부재료 첨가량이 증가할수록 점도가 낮아진다 고 보고하여 본 연구결과와는 차이를 보였는데, 이는 첨가 되는 부재료의 특성의 차이에 기인하는 것으로 생각된다.

\section{땅콩분말 죽의 관능검사}

땅콩분말의 첨가량을 달리한 땅콩 죽의 관능적 특성 검 사 결과를 Table 5에 나타내었는데, 모든 특성에서 유의적 차이를 보였다. 땅콩 죽의 색은 땅콩분말 $20 \%$ 첨가군의 경우에 가장 기호도가 높게 나타났으며, 다음으로 땅콩분 말 $60 \%$ 첨가군의 죽이 기호도가 높았다. 땅콩 죽의 향미는 땅콩분말 $20 \%$ 첨가군이 높게 나타났다. 점도는 대조군이 가장 낮았고, 땅콩분말의 첨가량이 증가할수록 높아지는 것으로 나타났다. 땅콩분말 죽의 고소한 맛과 씹힘성은 땅 콩분말 $60 \%$ 첨가군, $40 \%$ 첨가군 순으로 기호도가 높았다. 전체적인 기호도는 대조군의 경우 가장 낮았고, 땅콩분말 $40 \%$ 첨가군, $60 \%$ 첨가군 순으로 높게 나타났다. 따라서 땅콩분말을 부재료로 사용하여 죽을 제조할 때, 전통적인 품질 특성과 기능성을 고려한다면 사용농도는 $40 \%$ 정도의 농도가 적합할 것으로 판단되었다.

Table 4. Viscosity and spreadability of peanut (Arachis hypogaea L.) Jook with added peanut powder

\begin{tabular}{cccccc}
\hline & \multicolumn{5}{c}{ Samples ${ }^{1)}$} \\
\cline { 2 - 6 } Characteristics & Control & PF-20\% & PF-40\% & PF-60\% & PF-80\% \\
\hline Viscosity (cp) & $4753.25 \pm 42.11^{\mathrm{c} 2)}$ & $6531.33 \pm 21.05^{\mathrm{b}}$ & $6923.10 \pm 25.11^{\mathrm{b}}$ & $7255.21 \pm 16.23^{\mathrm{a}}$ & $7825.22 \pm 8.85^{\mathrm{a}}$ \\
Spreadability (cm) & $8.33 \pm 0.04^{\mathrm{a}}$ & $6.75 \pm 0.02^{\mathrm{b}}$ & $6.44 \pm 0.01^{\mathrm{b}}$ & $6.25 \pm 0.11^{\mathrm{c}}$ & $6.14 \pm 0.21^{\mathrm{d}}$ \\
\hline
\end{tabular}

${ }^{1)}$ Control, no peanut powder; PF-20\%, 20\% peanut powder; PF-40\%, 40\% peanut powder; PF-60\%, 60\% peanut powder; PF-80\%, $80 \%$ peanut powder.

${ }^{2)}$ Values are mean $\pm S D$. Means in a rows by different superscripts are significantly different by Duncan's multiple range test at $\mathrm{p}<0.05$.

Table 5. Sensory evaluation of peanut (Arachis hypogaea L.) Jook with added peanut powder

\begin{tabular}{ccccccc}
\hline Samples & Color & Flavor & Viscosity & Nutty taste & Chewiness & Overall preference \\
\hline Control & $2.81 \pm 0.24^{\mathrm{c} 2)}$ & $2.80 \pm 0.24^{\mathrm{c}}$ & $3.10 \pm 0.33^{\mathrm{d}}$ & $2.91 \pm 0.29^{\mathrm{d}}$ & $1.91 \pm 0.19^{\mathrm{d}}$ & $1.91 \pm 0.18^{\mathrm{d}}$ \\
PF-20\% & $3.30 \pm 0.32^{\mathrm{a}}$ & $3.30 \pm 0.31^{\mathrm{a}}$ & $3.31 \pm 0.32^{\mathrm{cd}}$ & $3.01 \pm 0.27^{\mathrm{c}}$ & $2.41 \pm 0.22^{\mathrm{c}}$ & $2.20 \pm 0.21^{\mathrm{c}}$ \\
PF-40\% & $2.82 \pm 0.25^{\mathrm{c}}$ & $2.80 \pm 0.27^{\mathrm{c}}$ & $3.52 \pm 0.28^{\mathrm{c}}$ & $3.11 \pm 0.27^{\mathrm{b}}$ & $3.01 \pm 0.25^{\mathrm{c}}$ & $3.51 \pm 0.52^{\mathrm{a}}$ \\
PF-60\% & $3.10 \pm 0.31^{\mathrm{ab}}$ & $3.10 \pm 0.30^{\mathrm{ab}}$ & $3.81 \pm 0.27^{\mathrm{b}}$ & $3.25 \pm 0.23^{\mathrm{a}}$ & $3.41 \pm 0.41^{\mathrm{a}}$ & $3.41 \pm 0.40^{\mathrm{ab}}$ \\
PF-80\% & $2.91 \pm 0.24^{\mathrm{b}}$ & $2.91 \pm 0.28^{\mathrm{b}}$ & $3.95 \pm 0.12^{\mathrm{a}}$ & $3.09 \pm 0.31^{\mathrm{b}}$ & $2.77 \pm 0.30^{\mathrm{b}}$ & $2.71 \pm 0.25^{\mathrm{b}}$ \\
\hline
\end{tabular}

${ }^{1)}$ Control, no peanut powder; PF-20\%, 20\% peanut powder; PF-40\%, 40\% peanut powder; PF-60\%, 60\% peanut powder; PF-80\%, 80\% peanut powder.

${ }^{2)}$ Values are mean \pm SD. Means with different superscripts within columns are significantly different by Duncan's multiple range test at $\mathrm{p}<0.05$. 


\section{요 약}

본 연구는 땅콩의 우수한 영양적 효능과 생리활성을 활 용하여 영양적으로도 우수하면서 손쉽게 많은 양을 소비할 수 있는 땅콩분말을 첨가한 죽을 제조하여 그 품질특성을 조사하였다. 땅콩분말 첨가량에 따른 땅콩 죽의 $\mathrm{pH}$ 는 땅콩 분말 첨가량이 증가함에 따라 감소하는 경향을 나타내었 다. 색도는 땅콩분말 첨가량이 증가할수록 $\mathrm{L}$ 값(명도)은 감 소하였고, $\mathrm{a}$ 값(적색도)과 $\mathrm{b}$ 값(황색도)은 증가하였다. 땅콩 분말 첨가 죽의 퍼짐성은 대조군 6.44 에서 $80 \%$ 첨가군 6.14 로 감소하였으나 $(\mathrm{p}<0.05)$, 점도의 경우 대조군 4753.25 에서 $80 \%$ 첨가군 7825.22 로 증가하는 경향을 보였다. 관능적 특성 검사 결과 색과 향미는 땅콩분말 $20 \%$ 첨가군의 경우 에 가장 기호도가 높게 나타났다. 고소한 맛과 씹힘성은 땅콩분말 $60 \%$ 와 $40 \%$ 첨가군의 죽이 기호도가 높았다. 전 체적인 기호도에 있어서 대조군의 경우 가장 낮은 기호도를 나타냈고, $40 \%$ 첨가군이 가장 높게 나타났다. 이상의 결과 로 볼 때 땅콩분말을 첨가하여 물성과 기호도를 고려한 죽을 제조할 경우 땅콩분말을 $40 \%$ 첨가하는 것이 죽의 전통적인 품질 특성에 큰 영향을 주지 않으면서 기능성을 더해 줄 수 있을 것으로 사료된다.

\section{References}

1. Kim YH, Lim JK (2007) Korea tradition foods. Hyoilbooks, Seoul. Korea, p 35-41

2. Zhang X, Lee FZ, Kum JS, Eun JB (2002) The effect of processing condition on physicochemical characteristics on pine nut gruel. Korean J Food Sci Technol, 34, 225-231

3. Lee SJ, Park JH, Lee C, Moon BK (2013) Quality characteristics of seasoning with different particle size of Hericium erinaceus powder. Korean J Food Cookery Sci, 29, 741-747

4. Cho HS, Kim KH (2009) Assessment of quality characteristics of the shrimp power, Jook, for elderly foodservice operation. J Korean Soc Food Culture, 24, 419-425

5. Park BH, Cho HS (2009) Quality characteristics of Jook prepared with lotus root powder. J Korean Home Economics Association, 47, 79-85

6. Park BH, Cho HS, Jeon ER, Kim SD (2009) Quality characteristics of Jook prepared with lotus leaf powder. Korean J Food Cookery Sci, 25, 55-61

7. Shin KE, Choi SK, Rha YA (2009) Quality characteristics of tarakjuk added with ginseng (Panax ginseng C.A.
Meyer). Korean J Culin Res, 15, 86-98

8. Kim JS, Kwak EJ (2011) Quality characteristics of gruel with added yam. J Korean Soc Food Culture, 26, 184-189

9. Song WJ, Jeong GY, Kim YS, Hong WS, Han JA, Lee JS (2012) A study on the quality of the rice porridge added seaweed powder. Academic publication of the Korean society of food \& cookery science, Seoul, Korea, 2, p 132

10. Lee SM (2013) Quality characteristics of gruel added with ramie leaves. Korean J Culin Res, 19, 76-86

11. Lee SM (2013) A study on the quality characteristics of gruel supplemented with purple sweet potato. J East Asian Soc Dietary Life, 23, 234-240

12. Ahn JS, Kong SG, Cho SH (2013) Quality characteristics of Tarakjuk (milk porridge) prepared with brown rice. Korean J Food Nutr, 26, 508-514

13. Hong II, Choi SK (2014) A study on the development of burdock gruel. Korean J Culin Res, 20, 18-26

14. Park BH, Ko GM, Jeon ER (2015) Quality characteristics of Jook prepared with Hericium erinaceum powder. J Korean Soc Food Culture, 30, 227-232

15. Kwon SC, Park GY, Jeong JH, Lee KH (2008) Chemical composition Hericium erinaceum cultured by the extracts of Angelica keiskei and the byproduct of Angelica keiskei. J Korean Soc Food Sci Nutr, 37, 1168-1173

16. Lee SE, Park CH, Bang JK, Seong NS, Chung TY (2004) Comparison on antioxidant potential of several peanut varieties. J Korean Soc Food Sci Nutr, 33, 941-945

17. Park CH, Park HW (2002) Review of the studies on the qualities in peanut. Korean J Crop Sci, 47, 163-165

18. Lim JD, Yang DC, Yun SJ, Chung IM, Sung ES, Kim MJ, Yu CY (2004) Isolation and biological activity of resveratrol-3-O- $\beta-\mathrm{D}$-glucoside in transgenic Rehmannia glutinosa L. transformed by peanut resveratrol synthase gene (RS3). Korean J Medicinal Crop Sci, 12, 406-414

19. Wang KH, Lai YH, Chang JC, Ko TF, Shyu SL, Chiou RY (2005) Germination of peanut kernels to enhance resveratrol biosynthesis and prepare sprouts as a functional vegetable. J Agric Food Chem, 53, 242-246

20. Kang HI, Kim JY, Kwon SJ, Park KW, Kang JS, Seo KI (2010) Antioxidative effects of peanut sprout extracts. J Korean Soc Food Sci Nutr, 39, 941-946

21. Reaven PD (1994) Mechanisms of atherolsclerosis role of LDL oxidation. In Free Radicals in Diagnostic Medicine. Armstrong D, ed. Plenum Press, New York, p 113-128

22. Chanvitavapongs S, Draczynska LB, Sun AY (1997) 
Amelioration of oxidative stress by antioxidants and resveratrol in PC 12 cells. Neuroreport, 14, 1499-1502

23. Hwang JY, Shue YS, Chang HM (2001) Antioxidative activity of roasted and defatted peanut kernels. Food Res Int, 34, 639-647

24. Wee JH, Park KH (2000) Identification of 3-methyoxy4-hydroxybenzoic acid with antioxidative and antimicrobial activity from Arachis hypogaea shell. Korean J Biotechnol Bioeng, 15, 464-468

25. Sekhon KS, Ahuja KL, Sandju RS, Bhatia IS (1972) Variability in fatty acid composition in peanut. I. Bunch group. J Sci Food Agri, 23, 919-924

26. Kim NS, Lee KT (2004) Enzymatic synthesis of structured lipids containing conjugated linoleic acid from extracted corn and peanut oil. J Korean Soc Food Sci Nutr, 33, 1000-1005

27. Koh YH, Yoon SJ, Park JW (1999) Inactivation of copper, zinc superoxide dismutase by the lipid peroxidation products malondialdehyde and 4-hydroxynonenal. Biochem Molecular Biol, 32, 440-444

28. Inai ME, Kanbak G, Sunal E (2001) Antioxidant enzyme activities and malondialdehyde levels related to aging. Clinica Chimica Acta, 305, 75-80

29. Lee JI, Park HW, Han ED (1988) Review of the studies on the qualities in peanuts. Korean J Crop Sci, 33, 64-85
30. AOAC (1995) Official method of analysis 16th ed. Association of official analytical chemists, Washington DC, USA, p 10-40

31. Ryu SY, Cho YS, Cho YK, Jung AR, Shin JH, Yeo IO, Joo NM, Han YS (2007) The physicochemical and sensory characteristics of almond gruel according to the concentration and pretreatment of almonds. Korean $\mathbf{J}$ Food Cookery Sci, 23, 832-838

32. Lee MK, Choi SH, Lim HS, Ahn JS (2010) Quality characteristics of Jook prepared with green laver powder. Korean J Food Cookery Sci, 26, 552-558

33. Kim KH, Cho HS (2008) The physicochemical and sensory characteristics of Jook containing different levels of skate (Raja kenoje1) flour. J East Asian Soc Dietary Life, 18, 207-213

34. Manohar RS, Manohar B, Rao PH (1998) Rheological characterization of wheat porridge (cooked dalia), a semi liquid breakfast. Food J Cereal Sci, 27, 103-108

35. Kim JM, Suh DS, Kim YS, Kim KO (2004) Physical and sensory properties of pice gruels and cakes containing different levels of ginkgo nut powder. Korean J Food Sci Technol, 36, 410-415

36. Kim HA, Kim JH (2015) Optimization on Hobakjook (pumpkin soup) with added glutinous rice powder. J East Asian Soc Dietary Life, 25, 162-175 